\title{
KONSEP DAN INDIKATOR PEMBELAJARAN EFEKTIF
}

\author{
Bistari Basuni Yusuf \\ Pendidikan Matematika FKIP Untan \\ Email: bistari.bs@gmail.com
}

\begin{abstract}
Abstrak
Untuk mengkaji keefektifan suatu fokus pembelajaran yang umum dilakukan yakni berupa uji statistik seperti uji beda dengan melihat signifikansi efektifitasnya. Namun demikian, dapat juga dilakukan dengan memperhatikan kualitas pembelajaran yang dilakukan. Suatu penerapan pembelajaran yang memfokuskan pada model, metode, pendekatan, strategi, trik, teknik dan media, dapat dilakukan suatu kajian tentang keefektifan penggunaan salah satu bentuk pengkondisian pembelajaran tersebut. Ada lima indikator pembelajaran efektif, yaitu: (1) pengelolaan pelaksanaan pembelajaran, (2) proses komunikatif, (3) respon peserta didik; (4) aktifitas belajar, (5) hasil belajar. Untuk kelima indikator pembelajaran efektif saling terkait dan saling mendukung. Pembelajaran dikatakan efektif bila semua indikator dimaksud mencapai kategori minimal baik.
\end{abstract}

Kata kunci: Konsep, Indikator, Pembelajaran Efektif

\section{PENDAHULUAN}

Pelaksanaan sebuah pembelajaran di dalam kelas dipengaruhi oleh berbagai faktor. Diantara faktor tersebut, yaitu peserta didik, pengajar, dan fasilitas. Sehingga dalam pencapaian tujuan pembelajaran saat mengajar tiga faktor tersebut perlu dipertimbangkan. Harapan pengajar dalam pembelajaran yang dilakukan di kelas adalah informasi yang disampaikan dapat disimak dan dipahami oleh seluruh peserta didik. Harapan tersebut dapat dikatakan cukup ideal. Kenyataan yang dirasakan pengajar, umumnya berbeda dari yang diharapkan.

Penulis melakukan pengamatan dalam 4 pertemuan terakhir pada 3 guru yang berbeda bidang studi, wawancara pada guru tersebut dan wawancara dengan 3 peserta didik perwakilan pada bulan Sepetember 2017. Beberapa fakta yang muncul dalam proses belajar mengajar diantaranya: (1) proses belajar mengajar ada variatif tapi cenderung monoton, (2) respon peserta didik kurang positif; (3) aktiftas yang dilakukan dalam proses belajar mengajar kurang bervariasi; dan (4) hasil belajar yang diperoleh belum dijadikan tolok ukur untuk langkah berikutnya.

Proses belajar yang dilakukan 3 guru tersebut satu diantaranya cukup variatif dan 2 guru monoton. Variatif dalam proses belajar mengajar karena guru tersebut memberikan nuansa yang berbeda dengan sebelumnya serta peserta didik tidak dapat menduga tindakan yang akan guru lakukan. Sedangkan dua guru monoton dalam hal ini guru tersebut kurang mengambil tindakan yang konstruktif bila peserta didik dalam kondisi jenuh. Sehingga tindakan pembelajaran yang dilakukan guru selalu sama dengan sebelumnya, akibatnya peserta didik sudah dapat menduga tindakan tersebut.

Hasil wawancara dengan tiga peserta didik (mewakili kelompok atas, tengah dan bawah) diperoleh informasi bahwa perwakilan peserta didik kelompok atas dan tengah kurang merespon proses pembelajaran yang dilakukan guru karena materi yang disampaikan mereka kurang memahami. Respon positif kurang diberikan oleh banyak peserta didik pada guru yang kurang variatif dalam pembelajaran karena mereka mengganggap cara penyampaian guru kurang 
menarik dan memunculkan rasa penasaran.

Bila dikaji dari aktivitas belajar peserta didik, dapat dikatakan proses belajar mengajar yang dilakukan tiga guru tersebut dengan aktivitas tergolong baik. Sebab lebih 75\% peserta didik aktiv melakukan sesuai perintah yang guru berikan. Namun 25\% diatara peserta didik tersebut aktivitas belajar belum tergolong maksimal. Diantaranya peserta didik tersebut bersikap sekedar memberikan respon apa adanya, menyimak secara sungguh-sungguh hanya 15 menit awal, dan kurang menanggapi apabila diminta menyimak dengan baik.

Memperhatikan fakta yang muncul di atas, tentunya hal tersebut dapat saja terjadi pada kelaskelas lain, yang pembelajarannya dilakukan belum efektif. Keefektifan suatu proses belajar mengajar bila dilakukan dengan proses kegiatan belajar mengajar dilakukan tergolong komunikatif, tepat sasaran dan tercapai tujuan secara maksimal. Suatu proses belajar mengajar yang komunikatif berefek pada pengelolaan belajar, aktivitas belajar, respon belajar, dan pemahaman yang maksimal.

Dengan belajar, kondisi peserta didik dapat berubah. Perubahan yang terjadi dapat menyentuh tiga aspek, yakni kognitif, afektif dan psikomotor. Ketiga aspek tersebut memungkin untuk berubah dalam waktu yang sama. Namun demikian, sebagian besar perubahan yang menjadi fokus dalam pembelajaran lebih mengarah pada salah satu yang lebih dominan. Misal pembelajaran matematika lebih dominan pada perubahan aspek kognitif, pembelajaran olah raga lebih dominan pada perubahan aspek psikomotor, dan pembelajaran etika lebih dominan afektif. Belajar pada hakikatnya merupakan suatu usaha, suatu proses perubahan yang terjadi pada individu sebagai hasil dari pengalaman atau hasil dari pengalaman interaksi dengan lingkungannya (Tim Pengembang Ilmu Pendidikan, 2007: 329). Belajar merupakan suatu aktivitas yang dilakukan secara sadar untuk mendapatkan sejumlah kesan dari bahan yang telah dipelajari (Syaiful Bahri, 1994: 21).

Definisi yang tidak jauh berbeda dengan definisi di atas, dikemukakan oleh Cronbach (1963)dalam bukunya yang berjudul "Educational Psychology" sebagai berikut: "Learning is shown by change in behavior as a result of experience." Maksudnya bahwa dalam proses belajar, seseorang berinteraksi langsung dengan objek belajar dengan menggunakan semua alat indranya. Belajar dalam arti mengubah tingkah laku, akan membawa suatu perubahan pada individu-individu yang belajar. Perubahan itu tidak hanya berkaitan dengan penambahan ilmu pengetahuan, tetapi juga berbentuk kecakapan, keterampilan, sikap, pengertian, harga diri, minat, watak, penyesuaian diri. Menurut Hamalik (2002: 6) pembelajaran adalah suatu kombinasi yang tersusun meliputi unsur-unsur manusiawi (peserta didik dan guru), material (buku, papan tulis, kapur dan alat belajar), fasilitas (ruang, kelas audio visual), dan proses yang saling mempengaruhi mencapai tujuan pembelajaran.

Dapat disimpulkan bahwa secara umum pembelajaran adalah suatu kegiatan yang dilakukan oleh pengajar dalam kondisi tertentu, sehingga kognitif, afektif dan psikomotor peserta didik berubah ke arah yang lebih baik. Pembelajaran bertujuan membantu peserta didik agar memperoleh berbagai pengalaman. Berdasarkan pengalaman tersebut tingkah laku peserta didik yang meliputi pengetahuan, keterampilan, dan nilai atau norma yang berfungsi sebagai pengendali sikap dan perilaku peserta didik menjadi bertambah, baik kuantitas maupun kualitasnya.

Efektif adalah perubahan yang membawa pengaruh, makna dan manfaat tertentu. Pembelajaran yang efektif ditandai dengan sifatnya yang menekankan pada pemberdayaan peserta didik secara aktif. Pembelajaran menekankan pada penguasaan pengetahuan tentang apa yang dikerjakan, tetapi lebih menekankan pada internalisasi, tentang apa yang dikerjakan sehingga tertanam dan berfungsi sebagai muatan nurani dan hayati serta dipraktekkan dalam kehidupan oleh peserta didik (Mulayasa, 2003: 49). Dapat disimpulkan bahwa pembelajaran efektif merupakan sebuah proses perubahan seseorang dalam kognitif, tingkah laku dan psikomotor dari hasil pembelajaran yang ia dapatkan dari pengalaman dirinya dan dari lingkungannya yang membawa pengaruh, makna dan manfaat tertentu. 
Dari defenisi belajar dan pembelajaran serta efektif, maka hakikat pembelajaran yang efektif adalah proses belajar mengajar yang bukan saja terfokus kepada hasil yang dicapai peserta didik, namun bagaimana proses pembelajaran yang efektif mampu memberikan pemahaman yang baik, kecerdasan, ketekunan, kesempatan dan mutu serta dapat memberikan perubahan kognitif, prilaku, psikomotor dan mengaplikasikannya dalam kehidupan mereka (Sri Esti Wuryani, 2002: 226).

Peran utama dalam pengajaran adalah menciptakan model aktivitas pengajaran kuat dan tangguh. Intinya adalah aktivitas pengajaran sebagai penataan lingkungan, pengaturan ruang kelas, yang didalamnya para pelajar dapat berinterkasi dan belajar mengetahui bagaimana caranya belajar. Berkaitan dengan efektivitas pengajaran, untuk mencapai pembelajaran aktif, satu aspek penting adalah masalah metode yang digunakan guru dalam menciptakan suasana aktif. Proses pembelajaran dengan dominan metode ceramah, guru mendominasi pembicaraan sementara peserta didik terpaksa atau bahkan dipaksa untuk duduk, mendengar dan mencatat hal ini sangat tidak dianjurkan. Pembelajaran diupayakan agar terpusat pada peserta didik.

Pembelajaran akan berjalan efektif jika pengalaman, bahan-bahan, dan hasil-hasil yang diharapkan sesuai dengan tingkat kematangan peserta didik serta latar belakang mereka. Proses belajar akan berjalan baik jika peserta didik bias melihat hasil yang fositif untuk dirinya dan memperoleh kemajuan-kemajuan jika ia menguasai dan menyelesaikan proses belajarnya (Dede Rosyada, 2004: 100). Gerak raga yang ditunjukkan harus sejalan dengan proses jiwa untuk mendapatkan perubahan sebagai hasil dari proses belajar. Sehingga dilihat dari pengertian prestasi dan belajar tersebut maka dapat diambil kesimpulan prestasi belajar adalah hasil yang diperoleh berupa kesan-kesan yang mengakibatkan perubahan. Bentuk perubahan dari hasil belajar meliputi tiga aspek, yaitu: (1) aspek kognitif meliputi perubahan-perubahan dalam segi penguasaan pengetahuan dan perkembangan eterampilan/kemampuan yang diperlukan untuk menggunakan pengetahuan tersebut; (2) aspek efektif meliputi perubahanperubahan dalam segi sikap mental, perasaan dan kesadaran; dan (3) aspek psikomotor meliputi perubahan-perubahan dalam segi bentuk-bentuk tindakan motorik. (Daradjat, 1995: 197) Prestasi belajar peserta didik yang diperoleh dalam proses belajar-mengajar disekolah dapat dilihat dan diketahui dari nilai hasil ujian semester, yang kemudian dituangkan dalam daftar nilai raport. Nilai tersebut merupakan nilai yang satunya dapat dijadikan acuan berhasil tidaknya peserta didik belajar serta dijadikan acuan berhasil tidaknya proses belajar mengajar di kelas.

Dalam kondisi ideal, setelah pembelajaran dilakukan maka diharapkan salah satu aspek terjadi perubahan pada peserta didik. Namun kenyataan yang terjadi bahwa tidak sedikit dari pelaksanaan pembelajaran lebih banyak peserta didik yang tak terjadi perubahan ke arah yang lebih baik. Hal ini menggambarkan bahwa pembelajaran yang dilakukan belum efektif. Ukuran efektif dalam proses belajar mengajar atau pembelajaran, berbagai ahli mengungkapkan pendapat masing-masing. Dari berbagai pendapat tersebut penulis mengkombinasikan beberapa indikator yang dianggap urgen untuk dimunculkan sebagai ciri pembelajaran yang dikatakan efektif. Kecenderungan beberapa ahli yang mengupas pembelajaran efektif sebagian besar bermuara pada proses belajar mengajar dan hasil akhir. Berikut beberapa pendapat ahli yang mengungkapkan tentang pembelajaran efektif.

Pertama, Wotruba dan Wright dalam Hamzah Uno (2013) mengungkapkan hasil kajiannya dalam beberapa penelitian mengungkapkan bahwa tujuh indikator pembelajaran dikatakan efektif, yaitu: (1) pengorganisasian materi yang baik, (2) komunikasi yang efektif, (3) penguasaan dan antusiasme terhadap materi pelajaran, (4) sikap positif terhadap peserta didik, (5) pemberian nilai yang adil, (6) keluwesan dalam pendekatan pembelajaran, dan (7) hasil belajar peserta didik yang baik. Dari tujuh indikator tersebut indikator pemberian nilai yang adil dan indikator keluwesan dalam pendekatan pembelajaran tergolong indikator yang sukar terukur. Makna adil secara hakekakatnya sukar diwujudkan, dibandingkan jika dalam penilaian dilakukan secara objektif 
dan transparan. Sedangkan keluwesan dalam pendekatan pembelajaran tergolong indikator yang sukar diwujudkan oleh setiap pengajar, karena bersikap luwes ada keterkaitannya dengan kepribadian dan kebiasaan.

Kedua, Reigeluth

(1983: 234) mengungkapkan, indikator pembelajaran efektif yaitu: (1) Kecermatan penguasaan; (2) Kecepatan unjuk kerja; (3) Tingkat alih belajar; dan (4) Tingkat retensi. Untuk kecermatan penguasaan dapat difokuskan pada peserta didik maupun pengajar. Peserta didik dengan penguasaan yang baik setelah pembelajaran itu berarti tujuan pembelajaran sudah tercapai. Sedangkan bagi pengajar yang memiliki kecermatan penguasaan tergolong baik, hal ini merupakan modal utama dalam proses belajarar mengajar untuk sampai pada tujuan pembelajaran yang ditetapkan. Kecepatan unjuk kerja dapat diartikan sebagai kemampuan secara cepat untuk memperlihatkan atau mengaplikasikan hasil suatu pembelajaran. Dengan kecepatan unjuk kerja di atas standar yang ditetapkan maka peserta didik mencapai tujuan pembelajaran secara maksimal. Terkait dengan tingkat alih belajar pada masingmasing peserta didik berbeda-beda tergantung kematangan penguasaan materi masingmasing. Bagi peserta didik dengan penguasaan pembelajaran cepat tentunya memiliki tingkat alih belajar yang cepat, karena untuk beralih pada pembelajaran berikutnya tak jarang dipengaruhi oleh pemahaman pembelajaran sebelumnya.

Memperhatikan dua pendapat ahli tersebut tentang indikator pembelajaran efektif, suatu permasalahan yang dapat diungkapkan disini adalah bagaimana ragam indikator dari suatu pembelajaran dikatakan efektif? Tentunya pembelajarn yang dikatakan efektif tersebut memungkinkan untuk diupayakan oleh banyak pengajar, dapat diamati dengan jelas, dan terukur.

\section{PEMBAHASAN}

Pada bagian pendahuluan diungkapkan dua pendapat ahli entang indikator pembelajaran efektif. Pertama Wotruba dan Wright mengungkapkan tujuh indikator pembelajaran efektif dan Reigeluth mengungkapkan empat indikator pembelajaran efektif. Dari dua pendapat tersebut penulis mempertimbangkan objektiftas, ketercapaian dan aplikatif; maka dalam tulisan ini dipaparkan ada lima indikator pembelajaran efektif, yaitu: (1) pengelolaan pelaksanaan pembelajaran, (2) proses komunikatif, (3) respon peserta didik; (4) aktifitas belajar, (5) hasil belajar. Dengan demikian, pembelajaran dinyatakan efektif bila semua indikator tersebut dalam katagori minimal baik. Jika salah satu dari indikator yang dimaksud belum tergolong baik (ada yang belum mencapai 75\%), maka belum dapat dinyatakan efektif. Untuk itu disarankan agar menelusuri dan menemukan penyebab dari indikator dari pembelajaran efektif yang belum dinyatakan baik, selanjutnya perlu dikembangkan lebih lanjut. Berikut dirincikan dari masingmasing indikator pembelajaran efektif.

\section{Pengelolaan Pelaksanaan \\ Pembelajaran}

Pendahuluan. Pada kegiatan ini, guru menerangkan alasan-alasan mengapa pokok pembahasan tersebut perlu dibicarakan dan kaitannya dengan materi yang telah dijelaskan, menyampaikan tujuan pembelajaran dengan tepat, memotivasi peserta didik belajar, dan menjelaskan manfaat yang dapat diperoleh peserta didik secara kontekstual. Dapat juga melakukan pengecekan kesiapan peserta didik baik kesiapan mental atau fisik.

Pelaksanaan. Pada kegiatan pelaksanaan merupakan kegiatan inti dari setiap pertemuan, dengan demikian pengajar harus mengadakan persiapan yang matang, menguasai dengan baik semua materi yang akan disajikan, memberikan contoh dan ilustrasi yang jelas. Untuk tidak menimbulkan kesulitan pada peserta didik, maka selama menyajikan pokok-pokok utama yang penting, pengajar dapat memberi kesempatan kepada peserta didik untuk mengajukan pertanyaan. Atau bila perlu pengajar sendiri yang mengajukan pertanyaan untuk mendapatkan gambaran tentang daya serap peserta didik. Pengelolaan pelaksanaan pembelajaran yang baik sebenarnya sudah dapat tercermin dalam perumusan tujuan dan pemilihan bahan atau topik pada saat kegiatan pra-kontruksional, yaitu membuat rencana pembelajaran. Laksanakan 
proses pembelajaran Proses pemebelajaran yang baik tentunya yang sesuai rencana yang telah ditetapkan semula, kecuali kalau rencana itu telah ditentukansecara luwes, sepertimembahas tentang perkembangan mutakhir dalam yang berkaitan dengan materi pelajaran. Pengorganisasian materi pelajaran merupakan wewenang pengajar. Oleh karena itu, yang dapat menilai apakah pembelajaran telah terorganisasikan dengan baik adalah teman sejawat dalam bidang studi yang bersangkutan, kepala sekolah, dan peserta didik. Para peserta didik serinngkali mempunyai posisi terbaik dalam melakukan penilaian, karena mereka dapat membandingkan secara langsung pengajar yang satu dengan yang lainnya. Sedangkan teman sejawat atau kepala sekolah mungkin menilai berdasarkan data atau persiapan yang dilakukan oleh pengajar yang bersangkutan. Menurut Reigulth (1989), beberapa hal yang harus diperhatikan oleh guru pada tahap kegiatan inti adalah:

a. Membagi materi dalam beberapa pokok bahasan atau topik, kemudian memberi penjelasan singkat tentang kaitan antartopik dan memberitahukan jika uraian topik berikutnya perlu dikuasai terlebih dahulu.

b. Menjelaskan materi dengan bahasan yang mudah dipahami peserta didik disertai dengan contoh.

c. Menuliskan kata-kata kunci, dengan demikian peserta didik dapat melihat dengan jelas struktur materi yang disajikan.

d. Setelah topik selesai, dapat dilanjutkan dengan megadakan evaluasi singkat, untuk mengetahui daya serap peserta didik, kemudian dapat dilanjutkan dengan topik berikutnya.

e. Membedakan antara hal yang pokok dengan tambahan, peserta didik diberi tahu bagian pokok materi yang merupakan bagian penting, sedangkan yang lainnya adalah pelengkap saja.

f. Memberitanggapan terhadap pertanyaan yang diajukan peserta didik.

Penutup. Setiap penyajian selalu di akhiri dengan kegiatan penutup. Perlu diperhatikan bahwa pada tahap penutup selalu diharapkan pada persoalan kritis, karena perhatian dan minat peserta didik sudah sangat merosot. Pada kegiatan penutup, sebagai pengajar dapat merangkum kembali materi yang telah disajikan. Jika menggunakan papan tulis, dapat menggunakan struktur penyajian yang masih tertulis di papan tulis atau kata-kata kunci yang masih ada di media lainnya seperti LCD Proyektor, lakukan pengulangan dan penekanan pada slide-slide utama dan penting. Pada kegiatan penutup jangan sampai diabaikan hanya karena masalah waktu. Pengajar harus berusaha agar tetap ada waktu yang tersedia untuk melakukan kegiatan penutup. Kenyataan yang sering dihadapi adalah bila kegiatan penutup ini selesai diberikan padahal tanda waktu pembelajaran sudah berbunyi, sehingga perhatian peserta didik sudah tidak ada lagi. Kegiatan penutup mempunyai fungsi sebagai berikut:

a. Memberikan rangkuman kembali mengenai semua materi yang telah dibahas, bila pokok bahasan tersebut sudah diberikan dalam dua pertemuan, maka bagian penutup itu juga mencakup materi yang diberikan dalam pertemuan pertama.

b. Mengkaitkan pokok bahasan dengan pokok bahasan berikutnya.

c. Memberikan post test (jika ada) yang bertujuan mengetahui sejauh mana peserta didik menguasai materi yang disajikan atau latihan-latihan dan pekerjaan rumah yang harus dibuat untuk memantapkan teori.

d. Mengingatkan peserta didik untuk mempersiapkan pokok bahasan berikutnya.

Seperti halnya dengan mengawali pelajaran, untuk menutup pelajaran ada beberapa hal yang perlu diperhatikan agar pembelajaran dapat efektif, yaitu:

a. Kelola waktu dengan baik, jangan sampai materi yang diajarkan belum selesai, sedangkan waktu telah habis.

b. Peserta didik diberi penugasan dengan adanya pekerjaan rumah, katakanlah dibagian akhir pelajaran, tetapi bukan 
beberapa detik sebelum pelajaran berakhir. Jika diberikan terlalu awal, akan memberi peluang kepada peserta didik untuk berusaha mengerjakannya selama pelajaran berlangsung. Sedangkan jika diberikan terlalu lambat maka tidak ada kesempatan peserta didik untuk bertanya mengenai tugas yang diberikan, dan peserta didik harus merasa yakin bahwa merka dapat mengerjakan tugas

c. Akhiri pelajaran sedikit lebih dini daripada terlambat, peserta didik-peserta didik akan menghargai apabila pelajaran dapat berakhir tepat pada waktunya.

d. Meninggalkan kelas dengan tertib.

e. Buat kesimpulan pada akhir pelajaran dan sebaiknya katakan sesuatu yang menandakan pelajaran telah usai.

\section{Proses Belajar Mengajar \\ Komunikatif}

Pembelajaran komunikatif adalah sistem pembelajaran yang menekankan pada aspek komunikasi, interaksi, dan mengembangkan kompetensi kebahasaan, serta keterampilan berbahasa (menyimak, membaca, menulis, berbicara) sebagai tujuan pembelajaran bahasa dan mengakui bahwa ada kaitannya dengan kegiatan komunikasi dalam kehidupan seharihari. Ciri-ciri pembelajaran komunikatif, yaitu: (1) mengutamakan makna sebenarnya, (2) ada interaksi,(3)orientasi kompotensi,(4)menemukan kaidah berbahasa/berkomunikasi, dan (5) materi ajar bermakna. Pembelajaran dilakukan dengan mengutamakan makna sebenarnya daripada tata gramatikalnya. Terjadi kegiatan komunikasi fungsional dan interaksi sosial yang saling berkaitan antara pengajar dan peserta didik. Pembelajaran yang dilakukan berorientasi pada pemerolehan kompetensi komunikatif, bukan ketepatan gramatikal (pemahaman untuk dapat diterapkan dalam kehidupan sehari-hari). Kaidah dalam berbahasa atau berkomunikasi (simbolik, visual, lisan dan tulisan) digunakan dalam kondisi yang tepat. Materi pembelajaran memang dibutuhkan dan berangkat dari analisis kebutuhan berbahasa pembelajaran, sehingga materi yang disampaikan bermakna.

Kecakapan dalam penyajian materi termasuk pemakaian media dan alat bantu atau teknik lain untuk menarik perhatian peserta didik, merupakan salah satu karakteristik pembelajaran yang baik. Komunikasi yang efektif dalam pembelajaran mencakup penyajian yang jelas. Kelancaran berbicara, interpretasi gagasan abstrak dengan contoh-contoh, kemampuan bicara yang baik (nada, intonasi, ekspresi) dan kemampuan untuk mendengar. Sebagaimana halnya dengan pengorganisasian materi pelajaran, penilaian akan kemampuan berkomunikasi yang efektif ini juga dapat dilakukan dengan baik oleh para peserta didik. Sejak pada tahap pendahuluan pengajar dalam menyampaikan tujuan pembelajaran dengan cara menatap semua peserta didik dan mempastikan bahwa tujuan pembelajaran tersebut dapat disimak dengan baik oleh semua peserta didik. Pada tahap pelaksanaan, pengajar bijak dalam memilih metode, pendekatan, model bahkan media pembelajaran. Artinya, strategi pembelajaran yang digunakan menarik serta memperhatikan sebagian besar kemampuan peserta didik tersebut. Penutup, dilakukan evaluasi ringan disamping membuat kesimpulan. Agar komunikasi yang sudah dijalin, dihangatkan kembali dengan pertanyaan-pertanyaan kecil maupun inti, yang dapat berakibat terjadi komunikasi juga pada peserta didik.

\section{Respon Peserta didik}

Upayakan, selaku pengajar dapat menciptakan kesan yang menarik untuk sebagian besar peserta didik, sehingga dapat memberikan respon yang positif. Menurut Wortruba dan Wright (1975) sikap positif terhadap peserta didik dapat dicerminkan dalam beberapa cara, antara lain: (1) Guru memberi bantuan, jika peserta didiknya mengalami kesulitan dalam memahami materi yang diberikan; (2) Guru mendorong para peserta didiknya untuk mengajukan pertanyaan atau memberi pendapat; (3) Guru dapat dihubungi oleh peserta didiknya di luar jam pelajaran; dan (4) Guru menyadari dan peduli dengan apa yang dipelajari peserta didiknya.

Sikap positifsepertiini dapat ditunjukkan,baik kepada kelas kecil maupun kelas besar. Dalam 
kelas kecil ditunjukkan dengan cara memberikan perhatian pada per orang, sedangkan dalam kelas besar diberikannya kepada kelompok yang mengalami kesulitan. Respon peserta didik dalam pembelajaran yang dilakukan pengajar merupakan tanggapan dan reaksi dari peserta didik terhadap pengkondisian pembelajaran yang dilakukan pengajar. Pengkondisian pembelajaran tersebut akan ditanggapi oleh peserta didik secara bervariasi. Ada dua aspek respon peserta didik dalam pembelajaran yakni aspek tanggapan dan aspek reaksi. Aspek tanggapan meliputi antusias, rasa, dan perhatian. Sedangkan aspek reaksi meliputi kepuasan, keingintahuan, dan senang. Antusias merupakan wujud sikap yang ditunjukkan dengan sikap bersemangat dalam mersepon terhadap hal yang dikondisikan. Rasa merupakan tanggapan yang diberikan sesuai perasaan yang dialami. Sedangkan perhatian adalah salah satu aspek psikologis yang tertuju pada suatu objek yang datang dari dalam dan luar diri peserta didik. Kepuasan adalah suatu kondisi di mana keinginan dan harapan dipenuhi. Setiap layanan yang diberikan dinilai memuaskan apabila layanan tersebut dapat memenuhi keinginan seseorang.

Pengukuran kepuasan merupakan elemen penting dalam menyediakan layanan yang lebih baik, lebih efisien dan lebih efektif. Keingintahuan adalah modal sejati untuk belajar yang sebenarnya. Senang merupakan reaksi yang diberikan karena puas dan lega, tanpa rasa susah dan kecewa.

\section{Aktivitas Belajar}

Aktivitas belajar yang dimaksudkan disini adalah kegiatan belajar mengajar yang dilakukan pengajar dan peserta didik. Kegiatan tersebut dilakukan dengan cara memanfaatkan panca indera, mental dan intelektual. Diantara kegiatankegiatan yang dilakukan dalam proses belajar mengajar sebagai berikut.

a. Kegiatan mental yaitu berpikir dengan cara merenung, mengingat-ngingat, dan membuat keputusan.

b. Kegiatan mendengarkan yaitu menyimak audio/radio, mendengar penjelasan dan mendengar percakapan. c. Kegiatan visual yaitu melihat gambar, membaca, dan mengamati objek,

d. Kegiatan menulis yaitu mencatat, mengetik, merangkum, menyalin, mengerjakan tes, dan memproses dengan tulisan.

e. Kegiatan lisan yaitu mengemukakan ide, memberikan saran, wawancara, diskusi, bertanya, menjelaskan, dan bercerita.

f. Kegiatan menggambar yaitu membuat visual (grafik, diagram, bagan, peta, skema, bangun datar, kurva dan pola), dan melukis.

g. Kegiatan motorik yaitu latihan fisik, peragaan, eksperimen menggunakan alat, bermain disertai gerakan, dan menari.

h. Kegiatan emosional yaitu merasa bosan, tenang, gugup, kesal, antusias, berani, dan takut.

Dengan adanya pembagian jenis aktivitas di atas, menunjukkan bahwa aktivitas di sekolah maupun di kelas cukup kompleks dan bervariasi. Jika kegiatan-kegiatan yang konstruktif tersebut dapat tercipta di sekolah, tentunya sekolahsekolah dapat lebih dinamis, tidak membosankan dan benar-benar menjadi pusat aktivitas belajar yang maksimal.

\section{Hasil Belajar}

Dalam tulisan ini yang dimaksud hasil belajar peserta didik adalah kemampuan (kognitif, afektif dan psikomotor) yang dimiliki peserta didik setelah mengalami proses pembelajaran dari pengajar. Hasil belajar tersebut sebaiknya terukur baik secara kualitatif maupun kuantitatif. Ada dua faktor yang mempengaruhi hasil belajar, yaitu: faktor internal dan faktor eksternal. Faktor internal, yakni peserta didik itu sendiri. Hasil belajar yang diperoleh peserta didik secara dominan dipengaruhi oleh peserta didik sendiri, seperti bakat, intelektual dan kesiapan. Faktor ekstern yaitu faktor di luar peserta didik, seperti pengajar, lingkungan, fasilitas, materi ajar dan pengkondisian pembelajaran. Pengajar dalam hal ini memiliki kontribusi terhadap hasil belajar peserta didik karena pengajar dapat menjadi motor/penggerak maupun fasilitator dalam 
pembelajaran. Lingkungan dalam hal ini seperti keluarga, kelas, sekolah dan masyarakat. Fasilitas yang kondusif dan relevan dengan materi ajar dapat mempermudah pemahaman peserta didik. Materi ajar yang sederhana atau kompleks cukup berpengaruh terhadap hasil belajar peserta didik. Pengkondisian pembelajaran yang dimaksud disini yakni penyesuaian pendekatan, metode, model, teknik, strategi dan media belajar yang digunakan oleh pengajar dalam upaya menciptakan pembelajaran yang bermakna.

Proses belajar mengajar dikatakan tuntas untuk satu kelas bila paling sedikit $85 \%$ dari jumlah siswa di kelas tersebut memiliki hasil belajar mencapai Kriteria Ketuntasan Minimal (KKM). Sedangkan penggolangan hasil belajar dapat dicermati tabel berikut.

\section{Tabel. Kriteria Penskoran}

\begin{tabular}{|l|l|}
\hline $\begin{array}{c}\text { Perolehan Skor } \\
\text { (Skala 0-100) }\end{array}$ & \multicolumn{1}{c|}{ Kriteria } \\
\hline $85 \leq$ Skor $\leq 100$ & A (Sangat Baik) \\
\hline $75 \leq$ Skor $<85$ & B (Baik) \\
\hline $60 \leq$ Skor $<75$ & C (Cukup) \\
\hline $50 \leq$ Skor $<60$ & D (Kurang) \\
\hline $0 \leq$ Skor $<50$ & E (Sangat Kurang) \\
\hline
\end{tabular}

\section{KESIMPULAN DAN SARAN}

\section{Kesimpulan}

Memperhatikan pada bagian pembahasan, maka disimpulkan bahwa ada lima indikator pembelajaran efektif, yaitu: (1) pengelolaan pelaksanaan pembelajaran, (2) proses komunikatif, (3) respon peserta didik; (4) aktifitas belajar, (5) hasil belajar. Untuk kelima indikator pembelajaran efektif saling terkait dan saling mendukung. Pembelajaran dikata-kan efektif bila semua indikator dimaksud mencapai kategori minimal baik.

\section{Saran}

Beberapa hal yang dapat disarankan, yaitu: (1) jika salah satu indikator pembelajaran efektif belum mencapai dalam kategori minimal baik, maka perlu dicari penyebabnya untuk di atasi kembali; (2) perlu teman sejawat dalam prosesnya, agar tidak terjadi subyektivitas, dan (3) perlu wawancara siswa untuk menggali lebih dalam informasi yang telah dilakukan.

\section{DAFTAR PUSTAKA}

Darajat. (1988) Proses Belajar Mengajar. Bandung: Remaja Karya.

Dede Rosyada. (2004). Paradigma Pendidikan Demokratis: sebuah Model Pelibatan Masyarakat dalam Penyelenggaraan Pendidikan. Jakarta: Prenada Media.

Djamarah, Syaiful Bahri. \& Zain Aswan. (2010). Strategi Belajar Mengajar. Jakarta: Rineka Cipta.

Lee Joseph Cronbach. (1963). Educational Psychology. New York: Harcourt, Brace \& World.

Mulyasa. E. (2003). Menjadi Kepala Sekolah Profesional: Dalam Konteks Menyukseskan $M B S$ dan KBK. Bandung: Remaja Rosdakarya.

Oemar Hamalik. (2002). Kurikulum dan Pembelajaran. Jakarta : PT. Bumi Aksara.

Reigeluth, C.M. (1983). Instruction Design Theories and Models, an Overview of Their Current Status. London: Lawrence Erlbaum Associates Publishers.

Sri Esti Wuryani Djiwandono. (2002). Psikologi Pendidikan. Jakarta: PT Grasindo.

Syaiful Bahri Djamarah. (1994). Guru dan Anak Didik dalam Interaksi Edukatif. Jakarta: Rineka Cipta.

Tim Pengembang Ilmu Pendidikan. (2007). Ilmu dan Aplikasi Pendidikan. Jakarta: PT. Imtima.

Uno, Hamzah B. Dan Mohamad, Nurdin. (2011). Belajar dengan Pendekatan PAILKEM. Jakarta: Bumi Aksara.

Wasty Soemanto. (1998). Psikologi Pendidikan: Landasan Kerja Pemimpin Pendidikan. Jakarta: PT Rineka Cipta. 